\title{
Bigtooth Maples Exposed to Asynchronous Cyclic Irrigation Show Provenance Differences in Drought Adaptation Mechanisms
}

\author{
Emad Bsoul and Rolston St. Hilaire ${ }^{1}$ \\ Department of Plant and Environmental Sciences, New Mexico State University, Box 30003, Las Cruces, \\ NM 88003
}

\author{
Dawn M. VanLeeuwen \\ Agricultural Biometric Service, New Mexico State University, Box 30003, Las Cruces, NM 88003
}

\begin{abstract}
AdDitional Index words. Acer grandidentatum, relative water content, woody ornamental plants, relative growth rate, net assimilation rate

AbSTRACt. Ecological traits such as an extensive range of natural distribution and tolerance to varying soil conditions, suggest that bigtooth maples (Acer grandidentatum Nutt.) could be popular landscape trees. But information on the tolerance of bigtooth maples to environmental stresses, such as drought, is virtually nonexistent. We studied physiological, growth and developmental traits of bigtooth maple plants from 15 trees native to Arizona, New Mexico, Texas, and Utah. Plants were grown in pots in a greenhouse and maintained as well-irrigated controls or exposed to drought and irrigated in cycles based on evapotranspiration. The ratio of variable to maximal fluorescence $\left(F_{v} / F_{m}\right)$ was not different between drought-stressed and control plants, but the low $F_{v} / F_{m}$ in plants designated as LM2 from the Lost Maples State Natural Area in Vanderpool, Tex., suggests these plants were relatively inefficient in capturing energy at PSII. Plants from another tree (LM5) originating from Lost Maples State Natural Area maintained similar predawn water potentials between drought-stressed and control plants after five cycles of drought. Plants from Dripping Springs State Park in Las Cruces, N.M., and those from LM2 had a strong, significant linear relationship between transpiration and stomatal conductance. Drought-stressed plants from Dripping Springs State Park, two plant sources from the Guadalupe Mountains in Salt Flat, Tex., designated as GM3 and GM4, and plants from trees designated as LM1 and LM2, had high relative growth rates and net assimilation rates. Drought-stressed plants from three of the four Guadalupe Mountain sources (GM1, GM3, GM4) had among the longest and thickest stems. Drought reduced shoot and root dry weight (DW). Although bigtooth maples showed several provenance differences in drought adaptation mechanisms, the lack of an irrigation effect on biomass allocation parameters such as root to shoot DW ratio and leaf area ratio implies that altered biomass allocation patterns may not be a common drought adaptation mechanism in bigtooth maples. Plants from selected provenances from the Guadalupe Mountains and Lost Maples State Natural Area in Texas, and to a lesser extent, provenances from Dripping Springs State Park in New Mexico might hold promise for selecting bigtooth maples for arid environments.
\end{abstract}

Evidence suggests that ecotypes of maples (Acer L.) can be matched to specific landscape conditions (St. Hilaire, 2002; St. Hilaire and Graves, 1999). Also, maples indigenous to the United States can be grouped into regions based on their tolerance to drought (Kriebel, 1957). For example, drought-resistant trees are from central and southern regions of the United States, and the more drought-susceptible trees are from the northern part of the hardwood region. Although the geographical separation between the two regions is unclear, maple species in hot, dry climates have the highest drought tolerance (Kriebel, 1957). Similarly, St. Hilaire and Graves (2001) concluded that maple taxa from more xeric provenances of eastern North America are more likely to perform better in arid environments than plants from mesic environments. Thus, selection of maples from xeric regions is a strategy that could be used to choose plants for arid environments.

Bigtooth maple is indigenous only to North America and can be found on xeric and mesic sites (St. Hilaire, 2002). Currently,

Received for publication 23 June 2005. Accepted for publication 9 Mar. 2006 Contribution of the N.M. Agricultural Experiment Station, N.M. State Univ., Las Cruces. We thank the following collaborators for providing seeds: Tim Buchanan, Sheri Chavez, Gil Eckrich, Lee Hughes, Roger Kjelgren, Grant Madden, David Riskin

'Corresponding author; e-mail: rsthilai@nmsu.edu bigtooth maple is not a ubiquitous landscape tree, but several ecological attributes suggest that the plant may be amenable to widespread landscape use (St. Hilaire, 2002). The species has a contiguous geographic range that spans almost $18^{\circ}$ of latitude $\left(30.086^{\circ} \mathrm{N}\right.$ to $\left.47.656^{\circ} \mathrm{N}\right)$ and includes regions in Utah, Idaho, Wyoming, Arizona, New Mexico, Texas, and Oklahoma. Bigtooth maple also occurs as a disjunct population in the Wichita Mountains of Oklahoma (Little, 1944). This wide geographic range includes many variations in elevation (Barker, 1977), and edaphic conditions. The plant is hardy to $-40^{\circ} \mathrm{C}$ (Barker, 1974) and tolerates summer temperatures well above $38^{\circ} \mathrm{C}$.

Many species with large geographic ranges exhibit adaptations to local environments, including variation in morphology (St. Hilaire and Graves, 1999), gas exchange and plant-water relations (Abrams et al., 1990). Bigtooth maple is no exception. The plant shows variation in form (Barker, 1975, 1977; Olson and Gabriel, 1974) and fall foliage coloration (Tankersley, 1981). Leaf water potentials of bigtooth maple growing in Red Butte Canyon, Utah, increased with altitude (Dina et al., 1973) and in that same canyon, bigtooth maples from a mesic environment had higher water potentials than species growing in a xeric environment.

Although the selection of plants for managed landscapes could be facilitated if the physiological attributes of bigtooth maples from different provenances were known, this information is virtually 
nonexistent. The objective of this experiment was to select bigtooth maples from a wide geographic region in the United States and determine whether physiological, growth, and developmental attributes in response to water deficits are likely to contribute to the selection of plants suited to arid environments.

\section{Materials and Methods}

Plant material. Mature samaras of bigtooth maple were collected between 18 Aug. and 3 Nov. 2001, from 15 seed sources (trees) within the southwestern U.S. range of the species. Seed sources were coded to identify the single tree origin of the seeds (Table 1). Seed sources selected were one tree (AZ) from the Chiricahua Mountains of the Coronado National Forest, Douglas,

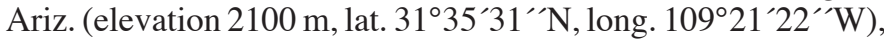
one tree (DS) from Dripping Springs State Park in Las Cruces, N.M. (elevation $1280 \mathrm{~m}$, lat. $32^{\circ} 23^{\prime} 20^{\prime \prime} \mathrm{N}$, long. $106^{\circ} 48^{\prime} 47^{\prime \prime} \mathrm{W}$ ), four trees (GM1, GM2, GM3, and GM4, respectively), from the Guadalupe Mountains in Salt Flat, Tex. (elevation 1680 m, lat. $31^{\circ} 54^{\prime} 00^{\prime \prime} \mathrm{N}$, long. $\left.104^{\circ} 52^{\prime} 01^{\prime \prime} \mathrm{W}\right)$, five trees (LM1, LM2, LM3, LM4, and LM5, respectively) from Lost Maples State Natural Area in Vanderpool, Tex. (elevation $580 \mathrm{~m}$, lat. $29^{\circ} 40^{\prime} 00^{\prime} \mathrm{N}$, long. $99^{\circ} 21^{\prime} 00^{\prime} \mathrm{W}$ ), and two trees from a north-facing slope (UN1 and UN2) and two trees (UW1 and UW2) from a west-facing slope in Logan Canyon, Utah (elevation 2300 m, lat. 41 46 $00^{\prime \prime} \mathrm{N}$; long. $\left.111^{\circ} 49^{\prime} 00^{\prime \prime} \mathrm{W}\right)$. Mean annual precipitation and mean annual maximum temperature at the sites were: Chiricahua Mountains $\left(356 \mathrm{~mm}, 21^{\circ} \mathrm{C}\right)$, Dripping Springs State Park $\left(291 \mathrm{~mm}, 33^{\circ} \mathrm{C}\right)$, Guadalupe Mountains ( $480 \mathrm{~mm}, 29^{\circ} \mathrm{C}$ ), Lost Maples State Natural Area (686 mm, $34^{\circ} \mathrm{C}$ ), and Logan Canyon $\left(454 \mathrm{~mm}, 31^{\circ} \mathrm{C}\right)$. Samaras were stratified at $4{ }^{\circ} \mathrm{C}$ in moist sphagnum. Between 28 Jan. and 20 Feb. 2002, seeds were sown in rows in greenhouse bench-top trays filled with 1 Canadian sphagnum peat moss (Voluntary Purchasing Groups, Bonham, Tex.) : 1 medium perlite (Therm-O-Rock, Therm-O-Rock West, Chandler, Ariz.) (by volume). During germination and seedling emergence, trays were misted with tap water as needed to keep the growing substrate moist. Between 3 Mar. and 15 May 2002, all seedlings that had the first pair of true leaves visible were transplanted individually in 3-L plastic pots (53 cm top i.d., $43 \mathrm{~cm}$ bottom o.d., $16.5 \mathrm{~cm}$ high) filled with the same growing substrate used for germination. Screens were placed at the bottom of the pots to retain the growing substrate. Air-filled porosity of the growing substrate was $28 \%$ and water holding capacity was $37 \%$ as determined by procedures of Handreck and Black (2002). Moisture release curves showed that moisture was released from the medium at suction pressure of up to $0.70 \mathrm{MPa}$. The medium was at field capacity at $0.1 \mathrm{MPa}$. Transplanted seedlings received weekly irrigation with a fertilizer solution ( $\mathrm{pH} 7.3$, electrical conductivity $1.2 \mathrm{dS} \cdot \mathrm{m}^{-1}$ ) containing $\mathrm{N}$ at $150 \mathrm{mg} \cdot \mathrm{L}^{-1}$ from a mixture of 1 Peter's Excel $(15 \mathrm{~N}-2.2 \mathrm{P}-12.5 \mathrm{~K})$ : 1 Peter's Professional (20N-4.4P-16.6K) fertilizer (Scotts, Marysville, Ohio) (by weight).

ENVIRONMENTAL CONDITIONS AND EXPERIMENTAL DESIGN. Samara germination, seedling growth, and the experiment were conducted in a greenhouse at New Mexico State Univ.'s Fabian Garcia Science Center in Las Cruces (lat. 34 $48^{\prime} 18^{\prime \prime} \mathrm{N}$, long. $\left.106^{\circ} 43^{\prime} 42^{\prime \prime} \mathrm{W}\right)$. Minimum photoperiod within the greenhouse was $16 \mathrm{~h}$. During samara germination and seedling growth, day/ night air temperatures averaged $26^{\circ} \mathrm{C} / 13^{\circ} \mathrm{C}$. During the experimental period, mean midday photosynthetic photon flux density as measured with a quantum sensor (LI-185; LI-COR, Lincoln, Nebr.) was $763 \mu \mathrm{mol} \cdot \mathrm{s}^{-1} \cdot \mathrm{m}^{-2}$. Daily temperature averaged $22{ }^{\circ} \mathrm{C}$. Relative humidity $(\mathrm{RH})$ of the air averaged $64 \%$. Air temperature and $\mathrm{RH}$ were measured with a combination temperature and humidity sensor (CS 500; Campbell Scientific, Logan, Utah). Sensors were monitored every $10 \mathrm{~min}$ and environmental data were averaged every hour. Sensors were connected to a datalogger (CR 10X; Campbell Scientific). Vapor pressure deficits existing at the time of physiological measurements are summarized in Table 1. On 21 May 2002, the 18 most uniform plants from each of 15 locations were assigned randomly to one of two irrigation treatments (drought and control). The experimental design was

Table 1. Seed source, growth characteristics, and biomass allocation patterns of 15 half-siblings of bigtooth maples harvested on the day irrigation treatments started. Dry weight (DW) data were used to calculate relative growth rates and net assimilation rates. Included are the number of drought cycles completed and the mean duration of each drought cycle that plants completed at the end of $113 \mathrm{~d}$ of drought treatment. Mean vapor pressure deficit (VPD) existing at the time of physiological measurement also is given.

\begin{tabular}{|c|c|c|c|c|c|c|c|c|c|}
\hline \multirow[b]{2}{*}{ Seed source } & \multirow{2}{*}{$\begin{array}{c}\text { Tree } \\
\text { designation }\end{array}$} & \multirow{2}{*}{$\begin{array}{l}\text { Plant } \\
\text { ht } \\
(\mathrm{cm})\end{array}$} & \multirow{2}{*}{$\begin{array}{c}\text { Total } \\
\text { leaf area } \\
\left(\mathrm{cm}^{2}\right)\end{array}$} & \multirow{2}{*}{$\begin{array}{l}\text { Shoot } \\
\text { DW } \\
(\mathrm{g})\end{array}$} & \multirow{2}{*}{$\begin{array}{c}\text { Root : } \\
\text { shoot } \\
\text { DW (ratio) }\end{array}$} & \multirow{2}{*}{$\begin{array}{c}\text { Leaf area/ } \\
\text { xylem } \\
\text { diam } \\
\left(\mathrm{cm}^{2} \cdot \mathrm{mm}^{-1}\right)\end{array}$} & \multicolumn{2}{|c|}{$\begin{array}{c}\text { Drought } \\
\text { cycles } \\
\text { completed }\end{array}$} & \multirow{2}{*}{$\begin{array}{l}\text { VPD } \\
(\mathrm{kPa})\end{array}$} \\
\hline & & & & & & & (no.) & [duration $(\mathrm{d})]$ & \\
\hline Chiricahua Mountains, Douglas, Ariz. & AZ & $7 \mathrm{~h}^{\mathrm{z}}$ & $42 \mathrm{f}$ & $0.333 \mathrm{f}$ & $0.751 \mathrm{~b}$ & $18 \mathrm{f}$ & 5 & 22 & $2.4 \pm 0.06$ \\
\hline Dripping Springs State Park, Las Cruces, N.M. & DS & $33 \mathrm{a}$ & $285 \mathrm{a}$ & $2.062 \mathrm{a}$ & $0.345 \mathrm{~b}$ & $80 \mathrm{a}$ & 5 & 18 & $2.3 \pm 0.06$ \\
\hline \multirow[t]{4}{*}{ Guadalupe Mountains, Salt Flat, Tex. } & GM1 & $18 \mathrm{c}$ & $82 \mathrm{~cd}$ & $0.778 \mathrm{~cd}$ & $0.331 \mathrm{~b}$ & 40 de & 5 & 17 & $2.6 \pm 0.06$ \\
\hline & GM2 & $34 \mathrm{a}$ & $294 \mathrm{a}$ & $1.580 \mathrm{~b}$ & $0.688 \mathrm{~b}$ & $93 \mathrm{a}$ & 5 & 20 & $2.5 \pm 0.06$ \\
\hline & GM3 & $15 \mathrm{c}-\mathrm{f}$ & $69 \mathrm{ef}$ & $0.399 \mathrm{ef}$ & $2.327 \mathrm{a}$ & $37 \mathrm{e}$ & 6 & 16 & $2.6 \pm 0.06$ \\
\hline & GM4 & $26 \mathrm{~b}$ & $146 \mathrm{c}$ & $0.990 \mathrm{c}$ & $0.239 \mathrm{~b}$ & $64 \mathrm{~b}$ & 5 & 16 & $2.5 \pm 0.06$ \\
\hline Lost Maples State Natural Area, & LM1 & $16 \mathrm{c}-\mathrm{e}$ & $88 \mathrm{~d}-\mathrm{f}$ & $0.605 \mathrm{~d}-\mathrm{f}$ & $0.422 \mathrm{~b}$ & 38 de & 6 & 16 & $2.8 \pm 0.06$ \\
\hline \multirow[t]{4}{*}{ Vanderpool, Tex. } & LM2 & $9 \mathrm{gh}$ & $78 \mathrm{~d}-\mathrm{f}$ & $0.481 \mathrm{~d}-\mathrm{f}$ & $0.188 \mathrm{~b}$ & $45 \mathrm{c}-\mathrm{e}$ & 7 & 17 & $2.5 \pm 0.06$ \\
\hline & LM3 & $11 \mathrm{f}-\mathrm{h}$ & $61 \mathrm{ef}$ & $0.387 \mathrm{ef}$ & $0.205 b$ & $34 \mathrm{e}$ & 5 & 21 & $2.6 \pm 0.06$ \\
\hline & LM4 & $13 \mathrm{~d}-\mathrm{g}$ & $101 \mathrm{~d}-\mathrm{f}$ & $0.632 \mathrm{~d}-\mathrm{f}$ & $0.314 b$ & $56 \mathrm{bc}$ & 5 & 20 & $2.6 \pm 0.06$ \\
\hline & LM5 & $10 \mathrm{gh}$ & $61 \mathrm{ef}$ & $0.324 \mathrm{f}$ & $0.240 \mathrm{~b}$ & $43 \mathrm{c}-\mathrm{e}$ & 7 & 19 & $2.6 \pm 0.06$ \\
\hline \multirow[t]{4}{*}{ Logan Canyon, Utah } & UN1 & $12 \mathrm{e}-\mathrm{h}$ & $88 \mathrm{~d}-\mathrm{f}$ & $0.615 \mathrm{~d}-\mathrm{f}$ & $0.435 \mathrm{~b}$ & $32 \mathrm{ef}$ & 5 & 22 & $2.4 \pm 0.06$ \\
\hline & UN2 & $11 \mathrm{f}-\mathrm{h}$ & $101 \mathrm{de}$ & $0.670 \mathrm{de}$ & $0.430 \mathrm{~b}$ & $22 \mathrm{e}$ & 5 & 20 & $2.3 \pm 0.06$ \\
\hline & UW1 & $17 \mathrm{~cd}$ & $117 \mathrm{~cd}$ & $0.725 \mathrm{~cd}$ & $0.417 b$ & $51 \mathrm{~b}-\mathrm{d}$ & 5 & 20 & $2.5 \pm 0.06$ \\
\hline & UW2 & $27 \mathrm{~b}$ & $194 \mathrm{~b}$ & $1.384 \mathrm{~b}$ & $0.388 \mathrm{~b}$ & $61 \mathrm{~b}$ & 6 & 16 & $2.4 \pm 0.06$ \\
\hline Means & & 17 & 121 & 0.798 & 0.515 & 48 & 6 & 19 & 2.5 \\
\hline$P$ & & $<0.0001$ & $<0.0001$ & $<0.0001$ & 0.01 & $<0.0001$ & --- & --- & --- \\
\hline
\end{tabular}

${ }^{2}$ Means $(\mathrm{n}=4)$ within columns were assessed at $P \leq 0.05$ using Proc Mixed, PDIFF option of SAS. Means sharing the same letter do not differ significantly at $P \leq 0.05$. 
a randomized complete block with nine blocks, 15 seed sources and two irrigation treatments.

INITIAL SEEDLING TRAITS. On 24 May 2002, irrigation treatments were initiated. On that day, two plants from each source in each of two blocks (four plants) were selected randomly and harvested destructively to determine initial seedling growth characteristics. Lamina surface area of leaves $\geq 2 \mathrm{~cm}$ long was measured with a leaf area meter (LI-3000A; LI-COR). Then, plant height was recorded as the length of stem from the growing substrate to uppermost bud. Xylem diameter (young and mature) was measured at $1 \mathrm{~cm}$ above the stem base after the bark was peeled back. Roots were washed free of growing substrate using water $1 \mathrm{~d}$ after stems were severed. Weights of leaves, stems and washed roots were determined after drying for $5 \mathrm{~d}$ at $65^{\circ} \mathrm{C}$. Seven blocks were retained to determine plant responses during and after exposure to drought.

Drought TREATMEnT. At drought treatment initiation, all plants were irrigated by hand to saturation with the fertilizer solution. For each source, three of the seven plants assigned to drought were chosen randomly to indicate the end of the drought cycle. Indicator plants were allowed to drain for $2 \mathrm{~h}$ and then weighed. Plants were weighed between 0900 and 1000 HR. Subsequently, irrigation was withheld from plants in the drought treatment. Drought treated plants received no further irrigation until a drought cycle ended. A drought cycle for each seed source ended when the combined weight of the indicator pots decreased by $56 \%$ to $57 \%$ due to evapotranspiration (ET). When the irrigation cycle ended, all drought-stressed plants within a source were irrigated by hand to saturation with the fertilizer solution. To facilitate saturation of pots in the drought treatment, pots were given three 2-min irrigations. Preliminary experiments with three plant sources showed that $56 \%$ moisture loss due to ET was severe enough to cause plant wilting but not mortality. At the end of each drought cycle volumetric moisture content of the upper $6 \mathrm{~cm}$ of the growing substrate was determined with a theta probe (type HH1; Delta-T Devices, Cambridge, U.K.) set on the organic option. Volumetric water content averaged $0.068 \pm 0.056 \mathrm{~m}^{3} \cdot \mathrm{m}^{-3}$ in droughted plants and $0.36 \pm 0.16 \mathrm{~m}^{3 \cdot \mathrm{m}^{-3}}$ in control plants. Control plants were irrigated every $2 \mathrm{~d}$ for $15 \mathrm{~min}$ using an automatic drip irrigation system. Plants received $1 \mathrm{~L}$ of water and the leaching fraction from the irrigated pots averaged $15 \%$.

Chlorophyll Fluorescence. At the end of each drought cycle, irrigation was withheld from plants until the next day. Between 1130 HR and 1400 HR on the same day that the drought cycle ended, $\mathrm{F}_{\mathrm{v}} / \mathrm{F}_{\mathrm{m}}$ was measured from the youngest fully expanded leaf from all (seven) plants in each source. Leaves were dark-adapted for $30 \mathrm{~min}$. Measurements were recorded using a continuous source fluorometer(OS-30; Opti-Sciences, Tyngsboro, Mass.). Fluorometer excitation source intensity was set at $3000 \mu \mathrm{mol} \cdot \mathrm{m}^{-2} \cdot \mathrm{s}^{-1}$.

Plant water Relations. At predawn (0300 to $0400 \mathrm{HR}$ ) on the day after a drought cycle ended, leaf water potential $\left(\Psi_{\mathrm{pd}}\right)$ was determined on the seven leaves previously chosen for fluorescence measurements by using a pressure chamber (PMS Instruments, Corvallis, Ore.). At midday (1130 to $1300 \mathrm{HR}$ ) of the same day, leaf water potential, transpiration and stomatal conductance $\left(g_{\mathrm{s}}\right)$ were measured. Transpiration and $g_{\mathrm{s}}$ were measured with a steady-state porometer (LI-1600; LI-COR) on the leaf opposite to the one selected for determining $\Psi_{\mathrm{pd}}$.

RELATIVE LEAF WATER CONTENT. The experiment was terminated on 14 Sept. 2002, 113 d after the start of the irrigation treatments. A fully expanded leaf was excised from a tree in each of five blocks, sealed in ziplock plastic bags, placed on ice and transported to our laboratory $(1.2 \mathrm{~km})$. Leaf disks $(0.785$ $\mathrm{cm}^{2}$ ) were excised with a cork borer from the interveinal region adjacent to the midvein but $2 \mathrm{~cm}$ from the petiole attachment from each leaf. Fresh weights (FW) were recorded. Then, disks were rehydrated with water for $10 \mathrm{~h}$, blotted on lintless paper to remove excess moisture and weighed to get the saturated weight (SW). Dry weights (DW) were recorded after drying at $85^{\circ} \mathrm{C}$ for $8 \mathrm{~h}$. Relative leaf water content was calculated as $\mathrm{RWC}=(\mathrm{FW}$ - DW $) /(\mathrm{SW}-\mathrm{DW}) \times 100 \%$.

SPECIFIC LEAF WEIGHT. A $0.785-\mathrm{cm}^{2}$ leaf disk was taken from the interveinal region opposite (opposite side of the midvein) the area where the leaf disk for RWC was taken. The disk was dried at $65^{\circ} \mathrm{C}$ for $5 \mathrm{~d}$. Specific leaf weight (SLW) was calculated by dividing the DW of the disk by its area.

SPeCIFIC STEM Length. Specific stem length was calculated by dividing stem length by stem dry weight. Stem length was measured $2.5 \mathrm{~cm}$ above the growing substrate and stem dry weight included all material, exclusive of leaves, severed above that point.

Microscopy. Leaf disks $\left(0.09 \mathrm{~cm}^{2}\right)$ were selected for microscopy from the area adjacent to the location where disks for SLW were taken. Samples were fixed in 0.2 M gluteraldehyde for 24 $\mathrm{h}$, then post fixed in $0.1 \mathrm{~m}$ osmium tetroxide for $2 \mathrm{~h}$. Samples were dehydrated through a graded ethanol series and incubated in acetone. Samples were embedded in Spurr's resin (Spurr, 1969) and prepared for imaging on a scanning electron microscope [SEM (S-3200N; Hitachi Instruments, San Jose, Calif.). The SEM was operated in the N-SEM mode and images were captured by a backscatter electron detector. Leaf thickness data were collected from SEM images. Two measurements of total leaf thickness, each $100 \mu \mathrm{m}$ apart, were taken and averaged.

FinAL HARVEST. All plants were harvested destructively on 14 Sept. 2002. Plant height, xylem diameter $2.5 \mathrm{~cm}$ above growing substrate level, total leaf surface area, and leaf, stem and root DW were determined using procedures described for the initial harvest.

Data ANALYSIS. Data were analyzed using SAS (version 9 for Windows; SAS Institute, Cary, N.C.). Initial destructive harvest data were subjected to analysis of variance procedures using Proc Mixed procedures and differences in least squares means were assessed at $P \leq 0.05$ using the PDIFF option. Relative growth rate (RGR) was used to determine the impact of irrigation treatment on plant growth. RGR was calculated using the equation of Gutschick and Kay (1995): RGR = $\left(\ln \mathrm{W}_{2}-\ln \mathrm{W}_{1}\right) /\left(\mathrm{T}_{2}-\mathrm{T}_{1}\right)$, where $\mathrm{W}_{2}$ was the final dry weight at day $113\left(\mathrm{~T}_{2}\right)$, and $\mathrm{W}_{1}$ was the initial DW determined from four seedlings per seed source before (day 0$)$ irrigation treatment $\left(T_{1}\right)$ began. Net assimilation rate (NAR) was used to calculate the efficiency of plants in accumulating dry matter (Balok and St. Hilaire, 2002). NAR was calculated as: $\mathrm{NAR}=\left(\mathrm{M}_{2}-\mathrm{M}_{1}\right) /\left(\mathrm{T}_{2}-\mathrm{T}_{1}\right) \times\left(\log \mathrm{L}_{2}-\log \mathrm{L}_{1}\right) /\left(\mathrm{L}_{2}\right.$ $\left.-L_{1}\right)$, where $M_{2}$ was the final dry weight at day $113\left(T_{2}\right), M_{1}$ was the initial DW determined from four seedlings per seed source before (day 0 ) irrigation treatment $\left(\mathrm{T}_{1}\right)$ began, and $\mathrm{L}_{2}$ and $\mathrm{L}_{1}$ were leaf area at $\mathrm{T}_{2}$ and $\mathrm{T}_{1}$. Data analysis for $\Psi_{\mathrm{pd}}, \Psi_{\mathrm{md}}, \mathrm{F}_{\mathrm{v}} / \mathrm{F}_{\mathrm{m}}, \mathrm{g}_{\mathrm{s}}$, transpiration, NAR, RGR, and final harvest data were executed using Proc Mixed procedures. Differences in least squares means were assessed at $P \leq 0.05$ using the PDIFF option. Analyses included repeated measures (drought cycles) utilizing compound symmetric (CS) covariance structure for the observations taken from the same tree. Kenward-Roger adjusted df were used. Fixed effects included treatment, source and drought cycles. Blocks represented random factors, and trees served as the experimental unit. A fixed effects nested model was used and drought cycle 
was not treated as a main effect factor under this model. Instead, drought cycle was nested within source because the nested model accommodated the different numbers of drought cycles that occurred within different seed sources. Correlations between stomatal conductance and transpiration were assessed using SAS software's PROC CORR.

\section{Results}

Initial seedling developmental traits showed that average plant height ranged from $7 \mathrm{~cm}$ in seedlings from AZ (Chiricahua Mountains), to $34 \mathrm{~cm}$ for seedlings from a tree (GM2) in the Guadalupe Mountains (Table 1). Seedlings from the tree designated as GM2 from the Guadalupe Mountains and those from DS (Dripping Springs State Park) had the greatest total leaf area (Table 1). Although plants from DS had the largest shoot (2.06 g) (Table 1) and root DW (0.75 g), seedlings from a tree designated as GM3 from the Guadalupe Mountains had the largest root to shoot DW ratio (2.33). Plants from a tree designated as GM2 and plants from Dripping Springs State Park had the largest leaf area to xylem diameter ratio. After plants were exposed to irrigation treatments, differences in evapotranspiration caused the duration of a drought cycle and the number of drought cycles to vary among seed sources (Table 1). Moisture depletion rates from pots were different for each source. The experiment was terminated on the same date for all sources which caused the number of drought cycles completed to vary among sources.

Variable to maximal fluorescence ratio was different among sources $(P<0.0001)$ (Fig. 1$)$, and drought cycles $(P<0.0001)$ (data not shown), but not between treatments $(P=0.512)$. The interaction between source and treatment $(P=0.7388)$ and between treatment and drought cycle $(P=1.000)$ were not significant. Plants designated as LM2 had the lowest $\mathrm{F}_{\mathrm{v}} / \mathrm{F}_{\mathrm{m}}(0.68)$ (Fig. 1).

Overall, predawn $\Psi_{\mathrm{pd}}$ was different among sources $(P=0.0013)$, drought cycles $(P<0.0001)$, and treatments $(P<0.0001)$. All the interactive effects were significant. At the end of their final drought cycle, tree sources that showed no differences between drought-stressed and well-watered plants included the Utah sources (UN1, UN2, UW1, and UW2) from Logan Canyon (Fig. 2A-D), plants from Dripping Springs State Park (DS) (Fig. 2E), two tree sources from Lost Maples State Natural Area (LM2 and LM4) (Fig. 2 F and G) and one plant source from the Guadalupe Mountains (GM1) (Fig. 2H). Drought-stressed plants from GM2 (Fig. 3A) had the lowest average $\Psi_{\text {pd }}(-2.5 \pm 0.17 \mathrm{MPa})$. At their final drought cycle, drought-stressed plants from Arizona (AZ) (not shown) and those from GM3, GM4, LM1, and LM3 (Figs. $3 \mathrm{~B}-\mathrm{E}$, respectively), had more negative $\Psi_{\mathrm{pd}}$ than controls. Plants from LM5 in Lost Maples State Natural Area had similar $\Psi_{\mathrm{pd}}$ between treatments and among drought cycles (Fig. 3F).

Midday leaf water potential $\left(\Psi_{\mathrm{md}}\right)$ was different among sources $(P<0.0001)$, drought cycles $(P<0.0001)$, and treatments $(P<$ $0.0001)$. Differences between irrigation treatments varied significantly with the source of the plant material $(P<0.0001)$, but not with the drought cycle $(P=0.2516)$. At their final drought cycle, tree sources that had similar $\Psi_{\text {md }}$ between treatments included three sources from Utah (Figs. 4A-C), plants from Arizona (not shown), plants from GM1 in the Guadalupe Mountains and plants from LM5 in Lost Maples State Natural Area (Fig. 5 E and F). Among all drought-stressed plants, those from GM2 (Fig. 5B) had the lowest $\Psi_{\text {md }}(-3.7 \pm 0.17 \mathrm{MPa})(P=0.0003)$. At their final drought cycle, plants from UW2, DS, LM1, LM2, LM3, LM4, GM2, GM3, and GM4 (Figs. 4D-H and 5A-D, respectively), had differences in $\Psi_{\text {md }}$ between treatments.

As expected, drought-stressed plants had less $g_{\mathrm{s}}$ than the controls $(P=0.0019)$. Among drought-stressed plants, those from LM3 had among the highest $g_{\mathrm{s}}$, while those from GM3 were among the lowest (Table 2). While the source $\times$ treatment interaction for $g_{\text {s }}$ was not significant $(P=0.0865)$, there was variation in treatment differences according to the drought cycle $(P=0.0009)$.

Transpiration rates differed among sources $(P<0.0001)$, treatments $(P<0.0001)$, and drought cycles $(P<0.0001)$. None of the interactive effects for transpiration were significant. Both drought-stressed and control plants from GM3 had among the lowest transpiration rates (Table 2).

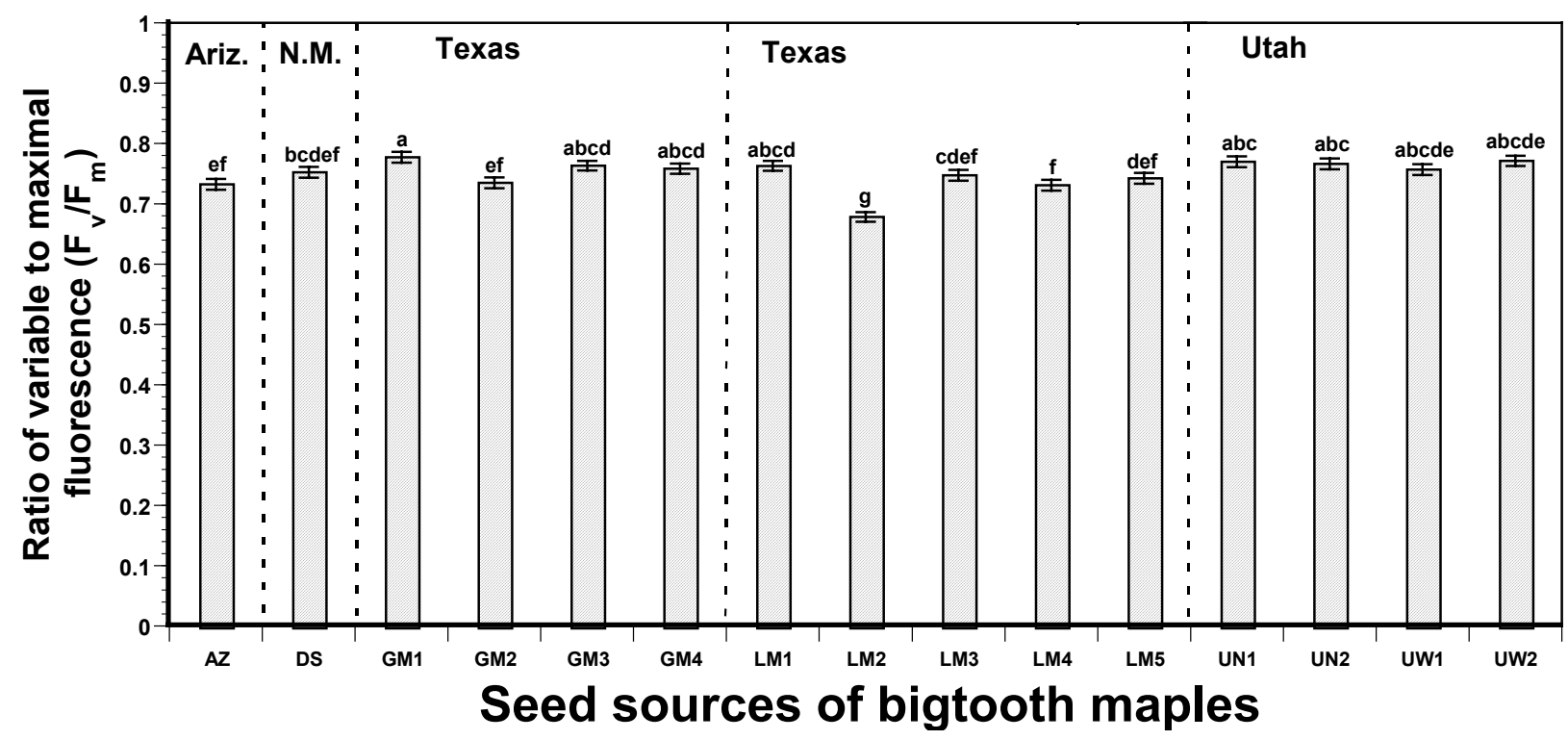

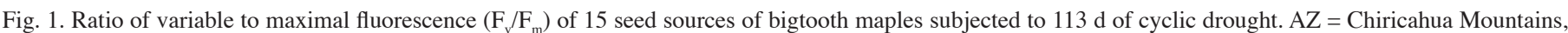

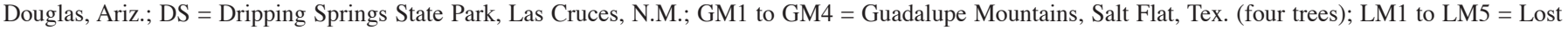

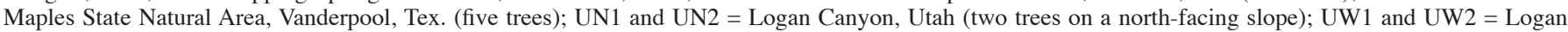

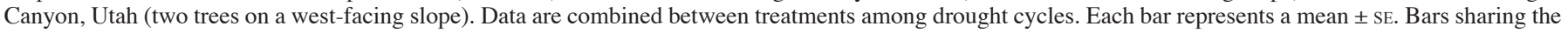
same letter do not differ significantly at $P \leq 0.05$ using the Proc Mixed, PDIFF option. 


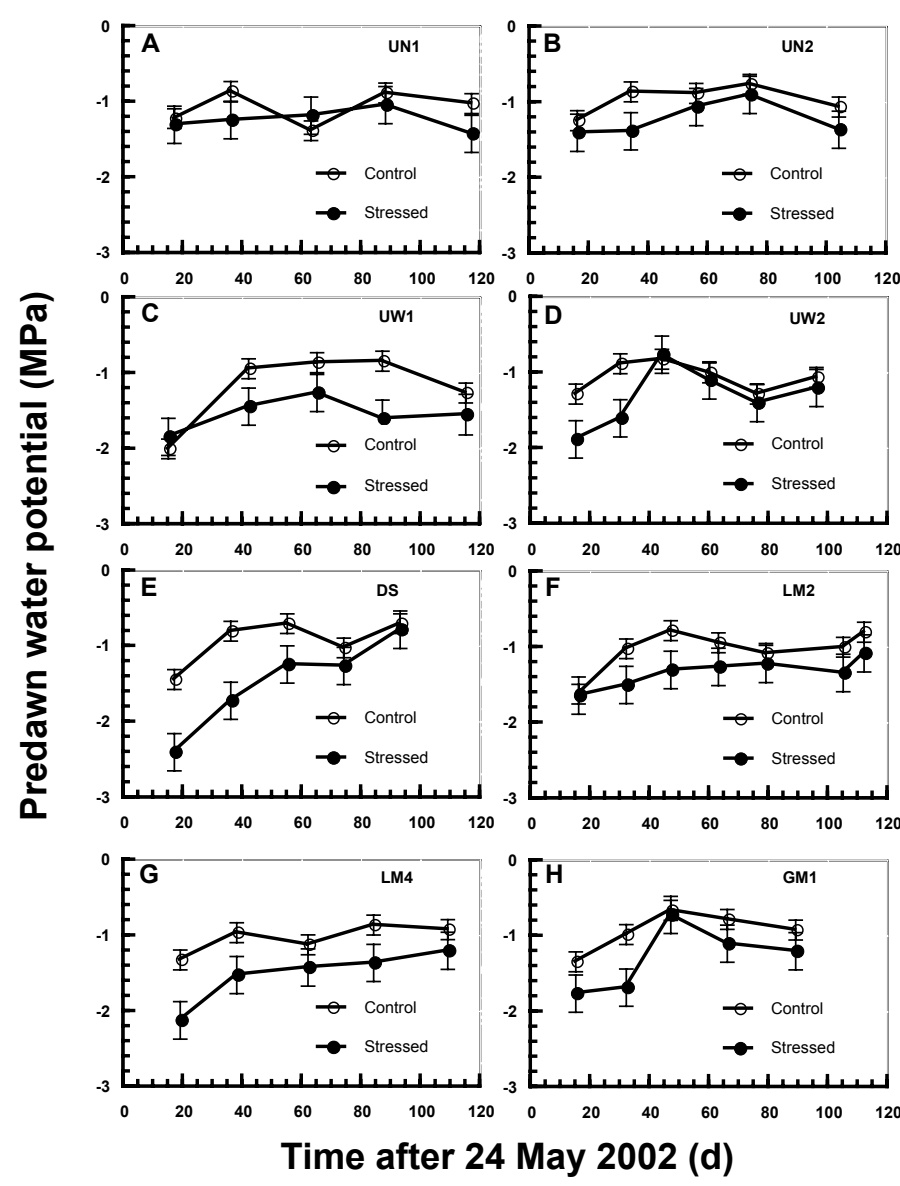

Fig. 2. Predawn water potential of seed sources of bigtooth maples subjected to $113 \mathrm{~d}$ of cyclic drought. (A, B) two trees (UN1, UN2) from a north-facing slope in Logan Canyon, Utah; (C, D) two trees (UW1, UW2) from a westfacing slope in Logan Canyon; (E) one tree (DS) from Dripping Springs State Park, Las Cruces, N.M.; (F, G) two trees (LM2, LM4) from Lost Maples State Natural Area, Vanderpool, Tex.; and (H) one tree (GM1) from the Guadalupe Mountains, Salt Flat, Tex. Each point represents a mean \pm SE $(n=7)$.

Although transpiration was significantly and positively correlated with $g_{\mathrm{s}}$ for drought-stressed and well-watered plants for several plant sources, the correlation between transpiration and $g_{\mathrm{s}}$ was very strong, positive and linear for plants from DS and LM2 (Table 2).

Irrigation treatment $(P<0.0001)$ and the origin of plants $(P<$ 0.0001 ) affected RGR (Fig. 6). RGR ranged from $0.021 \mathrm{~g} \cdot \mathrm{g}^{-1} \cdot \mathrm{d}^{-1}$ in drought-stressed plants from Arizona to $0.0416 \mathrm{~g} \cdot \mathrm{g}^{-1} \cdot \mathrm{d}^{-1}$ in wellirrigated plants from the tree GM3 in the Guadalupe Mountains (Fig. 6). Control plants from GM3 had nearly 1.7 times the RGR as control plants from AZ (Fig. 6). Overall, NAR was different between irrigation treatments $(P<0.0002)$ (Fig. 7), but not statistically different among seed sources $(P=0.1232)$. The NAR in drought-stressed plants averaged $0.178 \mathrm{mg} \cdot \mathrm{g}^{-1} \cdot \mathrm{d}^{-1}$, while that of control plants averaged $0.285 \mathrm{mg} \cdot \mathrm{g}^{-1} \cdot \mathrm{d}^{-1}$. Interactive effects of sources and treatment were not significant for RGR $(P=0.4958)$ and NAR $(P=0.4365)$.

After $113 \mathrm{~d}$ of cyclic drought, well-watered plants from GM3 were relatively tall $(117 \mathrm{~cm})$ while drought-stressed plants from the same source averaged $57 \mathrm{~cm}$ (Table 3$)$. Drought-stressed plants had less total leaf area compared with controls. Well-watered plants originating from GM3 had among the highest leaf area $\left(1524 \mathrm{~cm}^{2}\right)$ (Table 3). Drought-stressed plants had less shoot DW $(5.0 \mathrm{~g})$ than well-watered plants $(11.8 \mathrm{~g})$. Drought-stressed plants

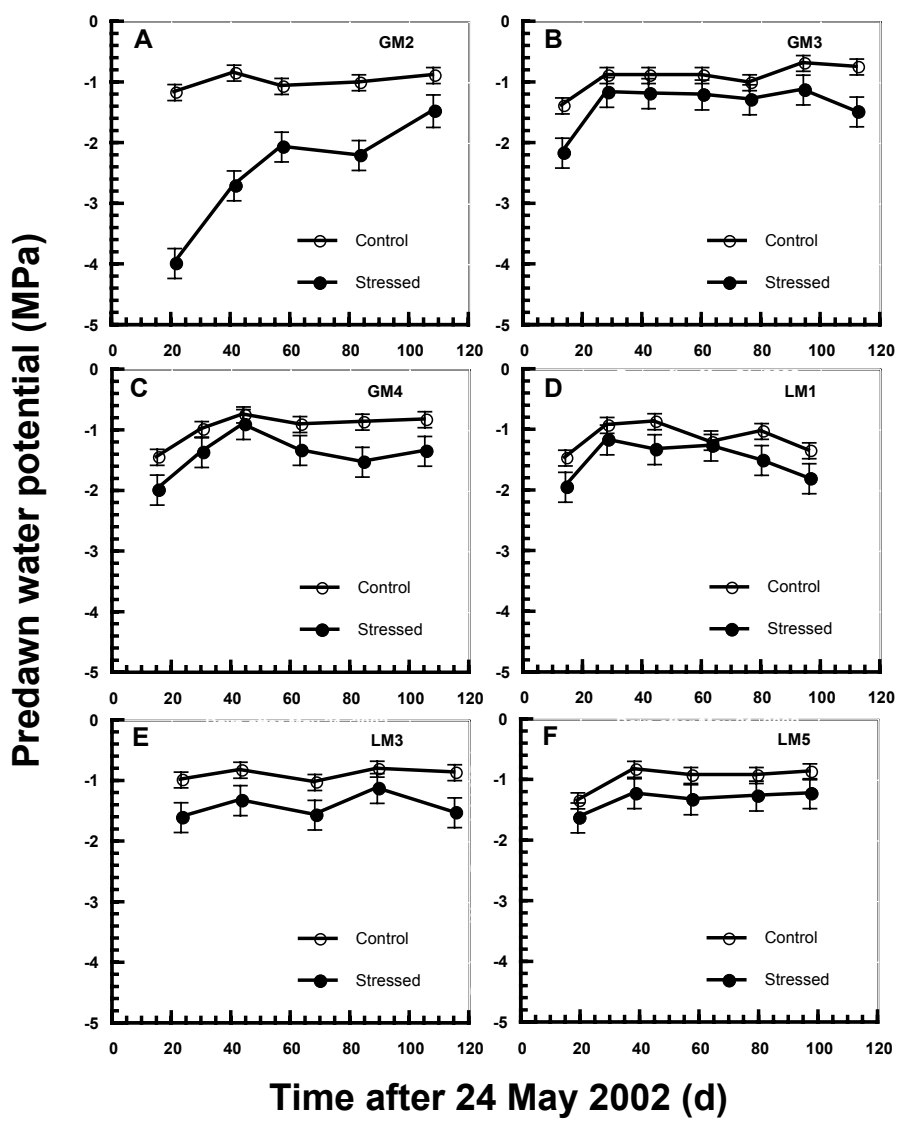

Fig. 3. Predawn water potential of seed sources of bigtooth maples subjected to $113 \mathrm{~d}$ of cyclic drought. (A, B, C) three trees (GM2, GM3, GM4) from the Guadalupe Mountains, Salt Flat, Tex.; and (D, E, F) three trees (LM1, LM3, and LM5) from Lost Maples State Natural Area, Vanderpool, Tex. Each point represents a mean $\pm \mathrm{SE}(\mathrm{n}=7)$.

had greater leaf area ratio than well-watered plants (Table 3).

Averaged over all provenances, well-watered plants accumulated 53\% more root DW than plants exposed to drought (10.30 g vs. 4.82 g) (Table 4). Root to shoot DW ratio was different among seed origin but similar between treatments (Table 4). All plants from Arizona had nearly three times the amount of dry matter partitioned into roots compared to shoots. Specific stem length (SSL) was greater in plants exposed to drought when there were treatment differences in SSL. Regardless of irrigation treatment, plants from GM1, GM3, and GM4 had among the lowest SSL (Table 4).

Leaf area to xylem diameter ratio had no differences among seed sources $(P=0.3709)$ or between treatments $(P=0.2165)$. Neither irrigation treatment $(P=0.4237)$ nor seed origin $(P=$ 0.2778 ) affected relative water content, which averaged $59 \%$. Specific leaf weight varied neither with irrigation treatment $(P=$ $0.3397)$ nor seed origin $(P=0.2353)$ and averaged $7.8 \mathrm{mg} \cdot \mathrm{cm}^{-2}$. Leaf thickness did not vary with seed origin $(P=0.7842)$ or irrigation treatment. Leaf thickness averaged $156 \mu \mathrm{m}$.

\section{Discussion}

Plant adaptations to drought stress are complex, reflecting various morphological, physiological, and molecular mechanisms required for plants to adapt to moisture deficits. Strategies that can be used to select plants for xeric environments include identifying plant from provenances that show superior adaptation to 

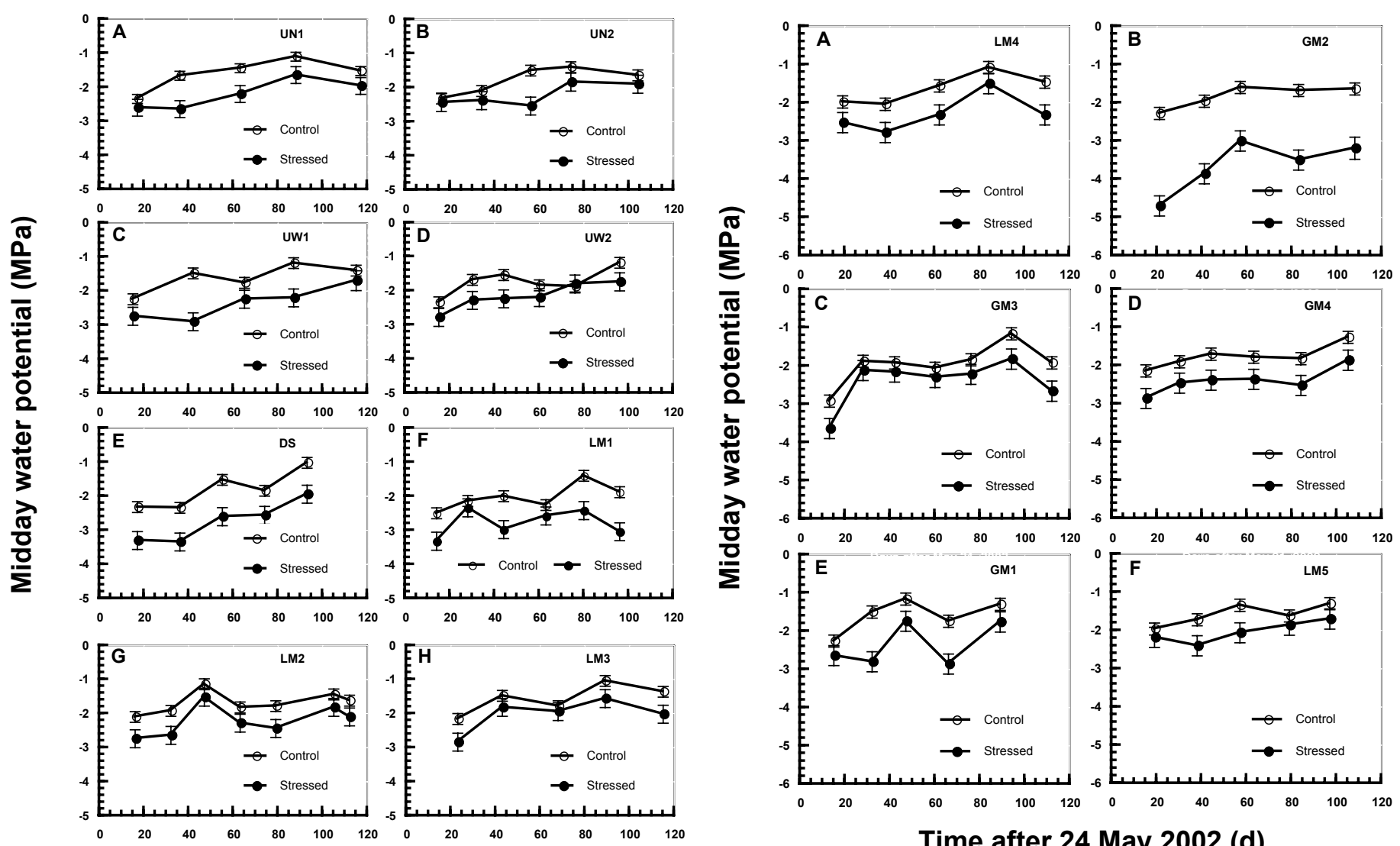

Time after 24 May 2002 (d)

Fig. 4. Midday water potential of seed sources of bigtooth maples subjected to 113 d of cyclic drought. (A, B) two trees (UN1, UN2) from a north-facing slope in Logan Canyon, Utah; (C, D) two trees (UW1, UW2) from a west-facing slope in Logan Canyon, Utah; (E) one tree (DS) from Dripping Springs State Park; and $(\mathbf{F}, \mathbf{G}, \mathbf{H})$ three trees (LM1, LM2, LM3) from Lost Maples State Natural Area, Vanderpool, Tex. Each point represents a mean \pm SE $(n=7)$.

Table 2. Correlation coefficient $\left(r^{2}\right)$ between transpiration and stomatal conductance $\left(g_{s}\right)$ for drought-stressed and control plant of bigtooth maples exposed to $113 \mathrm{~d}$ of cyclic drought treatments. The probability value $(P)$ for the $r^{2}$ also is given.

\begin{tabular}{|c|c|c|c|c|c|c|c|c|c|}
\hline \multirow[b]{2}{*}{ Seed source } & \multirow[b]{2}{*}{$\begin{array}{c}\text { Tree } \\
\text { designation }\end{array}$} & \multicolumn{4}{|c|}{ Drought } & \multicolumn{4}{|c|}{ Control } \\
\hline & & $\begin{array}{l}\text { Transpiration } \\
\left(\mathrm{mmol} \cdot \mathrm{m}^{-2} \cdot \mathrm{s}^{-1}\right)\end{array}$ & $\begin{array}{c}g_{s} \\
\left(\mathrm{mmol} \cdot \mathrm{m}^{-2} \cdot \mathrm{s}^{-1}\right)\end{array}$ & $r^{2}$ & $P$ & $\begin{array}{l}\text { Transpiration } \\
\left(\mathrm{mmol} \cdot \mathrm{m}^{-2} \cdot \mathrm{s}^{-1}\right)\end{array}$ & $\begin{array}{c}g_{s} \\
\left(\mathrm{mmol} \cdot \mathrm{m}^{-2} \cdot \mathrm{s}^{-1}\right)\end{array}$ & $r^{2}$ & $P$ \\
\hline Chiricahua Mountains, Douglas, Ariz. & $\mathrm{AZ}$ & $9.77 \mathrm{bc}$ & $480.9 \mathrm{~b}-\mathrm{d}$ & 0.121 & 0.653 & $12.06 \mathrm{bc}$ & $675.5 \mathrm{bc}$ & -0.481 & 0.888 \\
\hline \multicolumn{10}{|l|}{ Dripping Springs State Park, } \\
\hline Las Cruces, N.M. & DS & $7.17 \mathrm{~cd}$ & $385.2 \mathrm{c}-\mathrm{e}$ & 0.997 & 0.0004 & $9.49 \mathrm{c}-\mathrm{e}$ & $503.7 \mathrm{bc}$ & 0.995 & $<0.0001$ \\
\hline \multirow[t]{4}{*}{ Guadalupe Mountains, Salt Flat, Tex. } & GM1 & $8.82 \mathrm{bc}$ & $364.7 \mathrm{de}$ & 0.989 & 0.0005 & $9.39 \mathrm{c}-\mathrm{e}$ & $406.7 \mathrm{bc}$ & 0.987 & 0.0006 \\
\hline & GM2 & $7.62 \mathrm{~b}-\mathrm{d}$ & 305.6 de & 0.994 & 0.0002 & $14.69 \mathrm{ab}$ & $615.5 \mathrm{bc}$ & 0.936 & 0.007 \\
\hline & GM3 & $5.45 \mathrm{~d}$ & $171.8 \mathrm{e}$ & 0.535 & 0.099 & $7.21 \mathrm{e}$ & $288.1 \mathrm{c}$ & 0.857 & 0.008 \\
\hline & GM4 & $9.43 \mathrm{bc}$ & $452.8 \mathrm{~b}-\mathrm{e}$ & 0.960 & 0.0006 & $12.01 \mathrm{bc}$ & $605.9 \mathrm{bc}$ & 0.977 & 0.0002 \\
\hline Lost Maples State Natural Area & LM1 & $14.50 \mathrm{a}$ & $707.5 \mathrm{ab}$ & 0.139 & 0.627 & $17.07 \mathrm{a}$ & $563.2 \mathrm{bc}$ & 0.007 & 0.916 \\
\hline \multirow[t]{4}{*}{ Vanderpool, Tex. } & LM2 & $9.21 b c$ & $435.2 \mathrm{~b}-\mathrm{e}$ & 0.999 & $<0.0001$ & $10.20 \mathrm{c}-\mathrm{e}$ & $503.6 \mathrm{bc}$ & 0.991 & $<0.0001$ \\
\hline & LM3 & $14.99 \mathrm{a}$ & $879.8 \mathrm{a}$ & 0.995 & 0.0002 & $16.14 \mathrm{a}$ & $867.1 \mathrm{a}$ & 0.714 & 0.072 \\
\hline & LM4 & $7.42 \mathrm{~cd}$ & $349.8 \mathrm{de}$ & 0.992 & 0.004 & $8.06 \mathrm{de}$ & $412.9 \mathrm{bc}$ & 0.987 & 0.007 \\
\hline & LM5 & $10.32 \mathrm{bc}$ & $441.8 \mathrm{~b}-\mathrm{e}$ & 0.983 & 0.001 & $12.25 \mathrm{bc}$ & $551.1 \mathrm{bc}$ & 0.954 & 0.0042 \\
\hline \multirow[t]{4}{*}{ Logan Canyon, Utah } & UN1 & $9.81 \mathrm{bc}$ & $566.1 \mathrm{a}-\mathrm{d}$ & 0.977 & 0.002 & $11.75 \mathrm{bc}$ & $684.3 \mathrm{bc}$ & 0.992 & 0.0003 \\
\hline & UN2 & $8.15 \mathrm{~b}-\mathrm{d}$ & $422.3 \mathrm{~b}-\mathrm{e}$ & 0.267 & 0.373 & $9.89 \mathrm{c}-\mathrm{e}$ & $512.3 \mathrm{bc}$ & 0.993 & 0.0003 \\
\hline & UW1 & $9.73 \mathrm{bc}$ & $582.4 \mathrm{a}-\mathrm{d}$ & 0.970 & 0.015 & $11.17 \mathrm{~b}-\mathrm{d}$ & $654.1 \mathrm{bc}$ & 0.911 & 0.012 \\
\hline & UW2 & $10.74 \mathrm{~b}$ & $682.4 \mathrm{a}-\mathrm{c}$ & 0.989 & $<0.0001$ & $14.35 \mathrm{ab}$ & $756.9 \mathrm{~b}$ & 0.785 & $<0.0001$ \\
\hline Means & & $9.54 \pm 0.30$ & $482 \pm 28$ & & & $11.71 \pm 0.32$ & $640 \pm 40$ & & \\
\hline
\end{tabular}

${ }^{\mathrm{z}}$ Least squares means within a column sharing the same letter do not differ significantly at $P \leq 0.05$. 


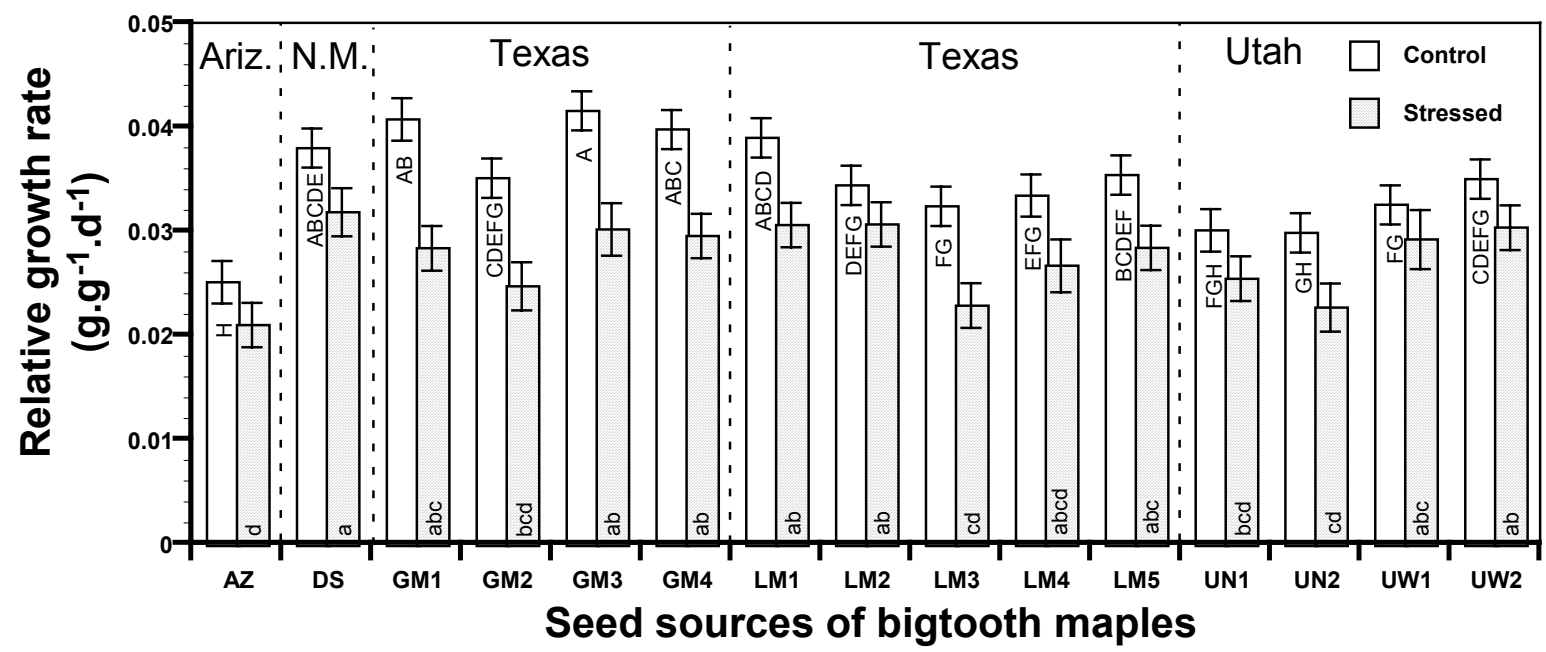

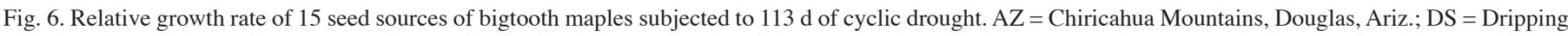

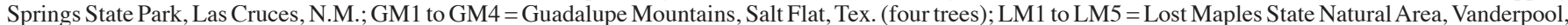
Tex. (five trees); UN1 and UN2 = Logan Canyon, Utah (two trees on a north-facing slope); UW1 and UW2 = Logan Canyon, Utah (two trees on a west-facing

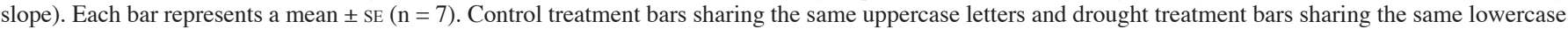
letter are not significantly at $P \leq 0.05$ using the Proc Mixed, PDIFF option.

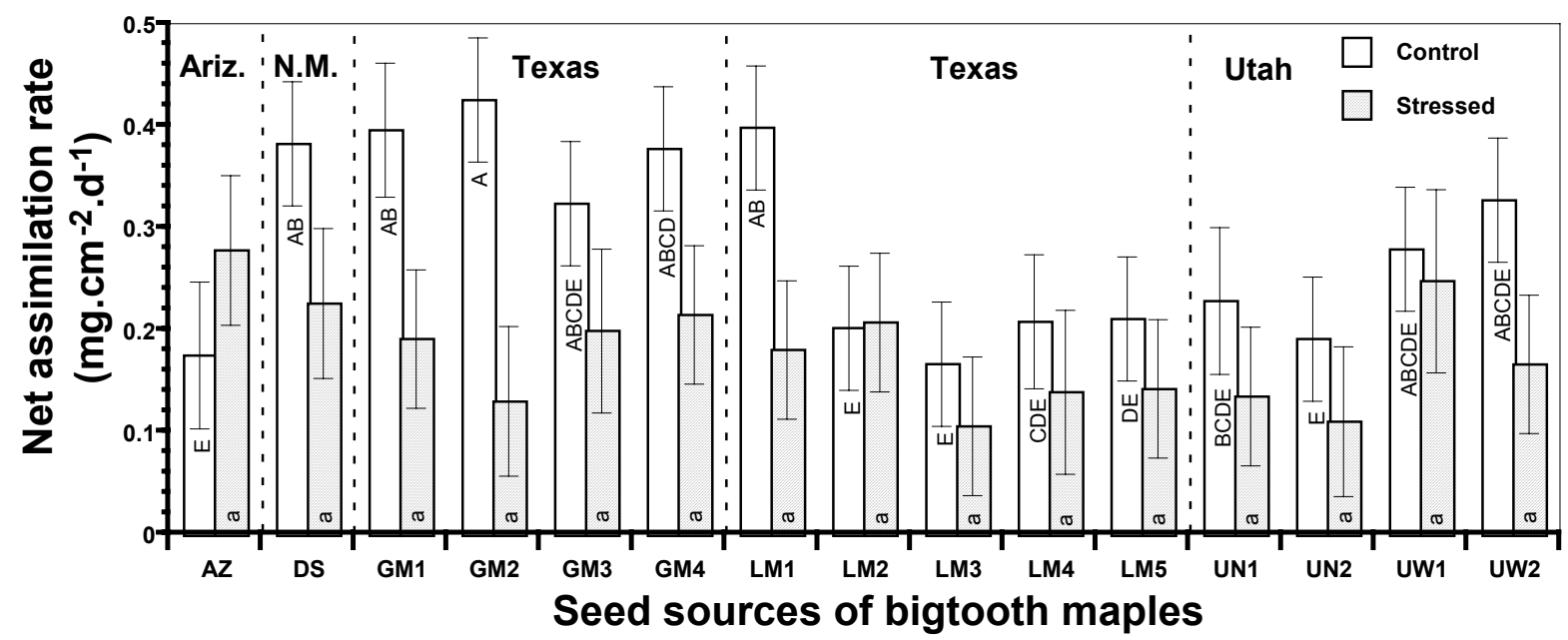

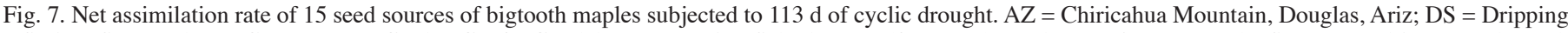

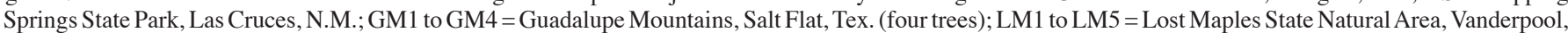
Tex. (five trees); UN1 and UN2 = Logan Canyon, Utah (two trees on a north-facing slope); UW1 and UW2 = Logan Canyon, Utah (two trees on a west-facing

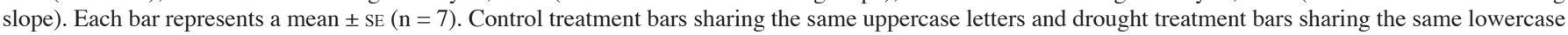
letter are not significantly at $P \leq 0.05$ using the Proc Mixed, PDIFF option.

drought stress (St. Hilaire and Graves, 2001) and rapid assessment of whole-plant performance to drought using chlorophyll fluorescence (Percival and Sheriffs, 2002). The ratio of variable to maximal fluorescence measures the efficiency of energy capture of the chloroplasts (Feser et al., 2005). Differences in $\mathrm{F}_{\mathrm{v}} / \mathrm{F}_{\mathrm{m}}$ among the sources suggest that $\mathrm{F}_{\mathrm{v}} / \mathrm{F}_{\mathrm{m}}$ could be used to assess the relative efficiency of energy capture. Plants from LM2 had the lowest $\mathrm{F}_{\mathrm{v}} / \mathrm{F}_{\mathrm{m}}(0.68)$. Because healthy tissues maintain $\mathrm{F}_{\mathrm{v}} / \mathrm{F}_{\mathrm{m}}$ near 0.8 (Mir et al., 1998), the low $\mathrm{F}_{\mathrm{v}} / \mathrm{F}_{\mathrm{m}}$ in LM2 plants suggests that plants from this source were relatively inefficient in capturing energy. Low $\mathrm{F}_{\mathrm{v}} / \mathrm{F}_{\mathrm{m}}$ values were not universal to the Lost Maples State Park provenance because plants from LM1 had $\mathrm{F}_{\mathrm{v}} / \mathrm{F}_{\mathrm{m}}$ values near that of nonstressed plants. We have little evidence to show that irrigation affected chlorophyll fluorescence in our bigtooth maple population. Chlorophyll fluorescence typically is affected only after severe drought stress (Baz and Fernandez, 2002), so the lack of an irrigation effect despite exposure to severe drought, provides some evidence that bigtooth maples may be resilient to drought.

Assuming that water potential between the leaf and soil equilibrated overnight, $\Psi_{\text {pd }}$ could represent an index of the severity of drought stress exposure. That drought-stressed plants from GM2 averaged $-2.5 \mathrm{MPa}$, illustrate the severity of the drought treatment to bigtooth maple plants compared to other maple taxa. For example, Zwack et al. (1998) reported that $\Psi_{\mathrm{pd}}$ of $-1.36 \mathrm{MPa}$ in the drought treatment reflected the severity of water deficit stress on three freeman maple (Acer $\times$ freemanii E. Murray) cultivars. The capacity to rehydrate tissues overnight might be a drought adaptation mechanism for plants from Lost Maples State Natural Area. For example, $\Psi_{\text {pd }}$ of drought-stressed and well-watered plants from the tree designated as LM5 were not different. This trait might be advantageous for plants grown in xeric environments. The $\Psi_{\text {md }}$ of drought-stressed plants from GM2 averaged $-3.65 \mathrm{MPa}$. Thus, these data provide further evidence of the 
Table 3. Growth traits and dry weights (DW) of 15 half-siblings of bigtooth maple seedlings harvested after $113 \mathrm{~d}$ of cyclic drought treatment.

\begin{tabular}{|c|c|c|c|c|c|c|c|c|c|}
\hline \multirow[b]{2}{*}{ Seed source } & \multirow{2}{*}{$\begin{array}{c}\text { Tree } \\
\text { designation }\end{array}$} & \multicolumn{2}{|c|}{ Plant ht $(\mathrm{cm})$} & \multicolumn{2}{|c|}{ Total leaf area $\left(\mathrm{cm}^{2}\right)$} & \multicolumn{2}{|c|}{ Shoot DW (g) } & \multicolumn{2}{|c|}{$\operatorname{LAR}^{\mathrm{Z}}\left(\mathrm{cm}^{2} \cdot \mathrm{g}^{-1}\right)$} \\
\hline & & Drought & Control & Drought & Control & Drought & Control & Drought & Control \\
\hline Chiricahua Mountains, Douglas, Ariz. & $\mathrm{AZ}$ & $32 \mathrm{c}-\mathrm{f}^{y}$ & $15 \mathrm{~g}$ & $191 \mathrm{c}$ & $289 \mathrm{ef}$ & $4.4 \mathrm{a}-\mathrm{c}$ & $2.7 \mathrm{f}$ & $57.8 \mathrm{ab}$ & $52.6 \mathrm{ab}$ \\
\hline Dripping Springs State Park, Las Cruces, N.M. & DS & $33 \mathrm{~b}-\mathrm{e}$ & 51 ef & $348 \mathrm{bc}$ & $475 \mathrm{c}-\mathrm{f}$ & $5.7 \mathrm{a}-\mathrm{c}$ & $9.9 \mathrm{~b}-\mathrm{d}$ & $27.9 \mathrm{~b}$ & $18.1 \mathrm{~b}$ \\
\hline \multirow[t]{4}{*}{ Guadalupe Mountains, Salt Flat, Tex. } & GM1 & $34 \mathrm{~b}-\mathrm{e}$ & $107 \mathrm{ab}$ & $283 \mathrm{bc}$ & $954 \mathrm{bc}$ & $4.5 \mathrm{a}-\mathrm{c}$ & $21.4 \mathrm{a}$ & $29.5 \mathrm{~b}$ & $26.2 \mathrm{~b}$ \\
\hline & GM2 & $42 \mathrm{a}-\mathrm{d}$ & 51 ef & $280 \mathrm{bc}$ & $396 \mathrm{~d}-\mathrm{f}$ & $4.8 \mathrm{a}-\mathrm{c}$ & $6.9 \mathrm{c}-\mathrm{f}$ & $30.1 \mathrm{ab}$ & $26.5 \mathrm{~b}$ \\
\hline & GM3 & $57 \mathrm{a}$ & $117 \mathrm{a}$ & $470 \mathrm{a}-\mathrm{c}$ & $1524 \mathrm{a}$ & $7.2 \mathrm{ab}$ & $24.7 \mathrm{a}$ & $46.4 \mathrm{ab}$ & $37.2 \mathrm{~b}$ \\
\hline & GM4 & $44 \mathrm{ab}$ & $102 \mathrm{ab}$ & $260 \mathrm{bc}$ & $912 b-d$ & $4.6 \mathrm{a}-\mathrm{c}$ & $20.2 \mathrm{a}$ & $27.7 \mathrm{~b}$ & $26.8 \mathrm{~b}$ \\
\hline \multirow{5}{*}{$\begin{array}{l}\text { Lost Maples State Natural Area, } \\
\text { Vanderpool, Tex. }\end{array}$} & LM1 & $41 \mathrm{~b}-\mathrm{d}$ & $95 \mathrm{a}-\mathrm{c}$ & $398 \mathrm{bc}$ & $830 \mathrm{~b}-\mathrm{e}$ & $6.3 \mathrm{a}-\mathrm{c}$ & $20.3 \mathrm{a}$ & $38.8 \mathrm{ab}$ & $31.0 \mathrm{~b}$ \\
\hline & LM2 & $33 \mathrm{~b}-\mathrm{e}$ & $79 \mathrm{~cd}$ & $472 \mathrm{~b}$ & $1054 \mathrm{ab}$ & $9.1 \mathrm{a}$ & $12.5 \mathrm{bc}$ & $44.3 \mathrm{ab}$ & $78.8 \mathrm{a}$ \\
\hline & LM3 & $23 \mathrm{ef}$ & $66 \mathrm{de}$ & $261 \mathrm{bc}$ & $746 \mathrm{~b}-\mathrm{f}$ & $3.4 \mathrm{~b} \mathrm{c}$ & $9.4 \mathrm{~b}-\mathrm{e}$ & $53.2 \mathrm{ab}$ & $49.0 \mathrm{ab}$ \\
\hline & LM4 & $27 \mathrm{~d}-\mathrm{f}$ & $50 \mathrm{ef}$ & $319 \mathrm{bc}$ & $777 \mathrm{~b}-\mathrm{f}$ & $5.2 \mathrm{a}-\mathrm{c}$ & $13.5 \mathrm{~b}$ & $51.1 \mathrm{ab}$ & $48.1 \mathrm{ab}$ \\
\hline & LM5 & $40 \mathrm{~b}-\mathrm{d}$ & $90 \mathrm{bc}$ & $451 \mathrm{bc}$ & $876 b-d$ & $4.7 \mathrm{a}-\mathrm{c}$ & $13.1 \mathrm{~b}$ & $52.5 \mathrm{ab}$ & $45.6 \mathrm{ab}$ \\
\hline \multirow[t]{4}{*}{ Logan Canyon, Utah } & UN1 & $16 \mathrm{f}$ & $17 \mathrm{~g}$ & $223 \mathrm{bc}$ & $248 \mathrm{f}$ & $4.0 \mathrm{c}$ & $2.0 \mathrm{~d}-\mathrm{f}$ & $37.3 \mathrm{ab}$ & $21.5 \mathrm{~b}$ \\
\hline & UN2 & $14 \mathrm{f}$ & $18 \mathrm{~g}$ & $210 \mathrm{bc}$ & $494 \mathrm{c}-\mathrm{f}$ & $2.0 \mathrm{bc}$ & $3.8 \mathrm{ef}$ & $46.9 \mathrm{ab}$ & $43.5 \mathrm{~b}$ \\
\hline & UW1 & $27 \mathrm{c}-\mathrm{f}$ & $40 \mathrm{fg}$ & $251 \mathrm{bc}$ & $330 \mathrm{ef}$ & $5.9 \mathrm{a}-\mathrm{c}$ & $5.2 \mathrm{~d}-\mathrm{f}$ & $24.4 \mathrm{~b}$ & $24.2 \mathrm{~b}$ \\
\hline & UW2 & $42 \mathrm{bc}$ & $59 \mathrm{~d}-\mathrm{f}$ & $747 \mathrm{a}$ & $685 \mathrm{~b}-\mathrm{f}$ & $5.5 \mathrm{a}-\mathrm{c}$ & $9.7 b-d$ & $70.2 \mathrm{a}$ & $29.4 \mathrm{~b}$ \\
\hline Means & & 34 & 64 & 344 & 706 & 5.0 & 11.8 & 42.5 & 37.2 \\
\hline Significance & & \multicolumn{8}{|c|}{$P$} \\
\hline Irrigation treatment & & \multicolumn{2}{|c|}{$<0.0001$} & \multicolumn{2}{|c|}{$<0.0001$} & \multicolumn{2}{|c|}{$<0.0001$} & \multicolumn{2}{|c|}{$<0.0001$} \\
\hline Seed source & & \multicolumn{2}{|c|}{$<0.0001$} & \multicolumn{2}{|c|}{$<0.0001$} & \multicolumn{2}{|c|}{$<0.0001$} & \multicolumn{2}{|c|}{$<0.0001$} \\
\hline Seed source $\times$ irrigation treatment & & \multicolumn{2}{|c|}{$<0.0001$} & \multicolumn{2}{|c|}{0.022} & \multicolumn{2}{|c|}{$<0.0001$} & \multicolumn{2}{|c|}{0.008} \\
\hline
\end{tabular}

${ }^{\mathrm{z}} \mathrm{LAR}=$ leaf area ratio.

${ }^{y}$ Least squares means (LSMeans) within columns sharing the same letter do not differ statistically. LSMeans differences were assessed at $P \leq 0.05$ using Proc Mixed, PDIFF option of SAS.

Table 4. Root dry weight, root:shoot dry weight and specific stem length of 15 seedling sources of bigtooth maples harvested after $113 \mathrm{~d}$ of cyclic drought treatment.

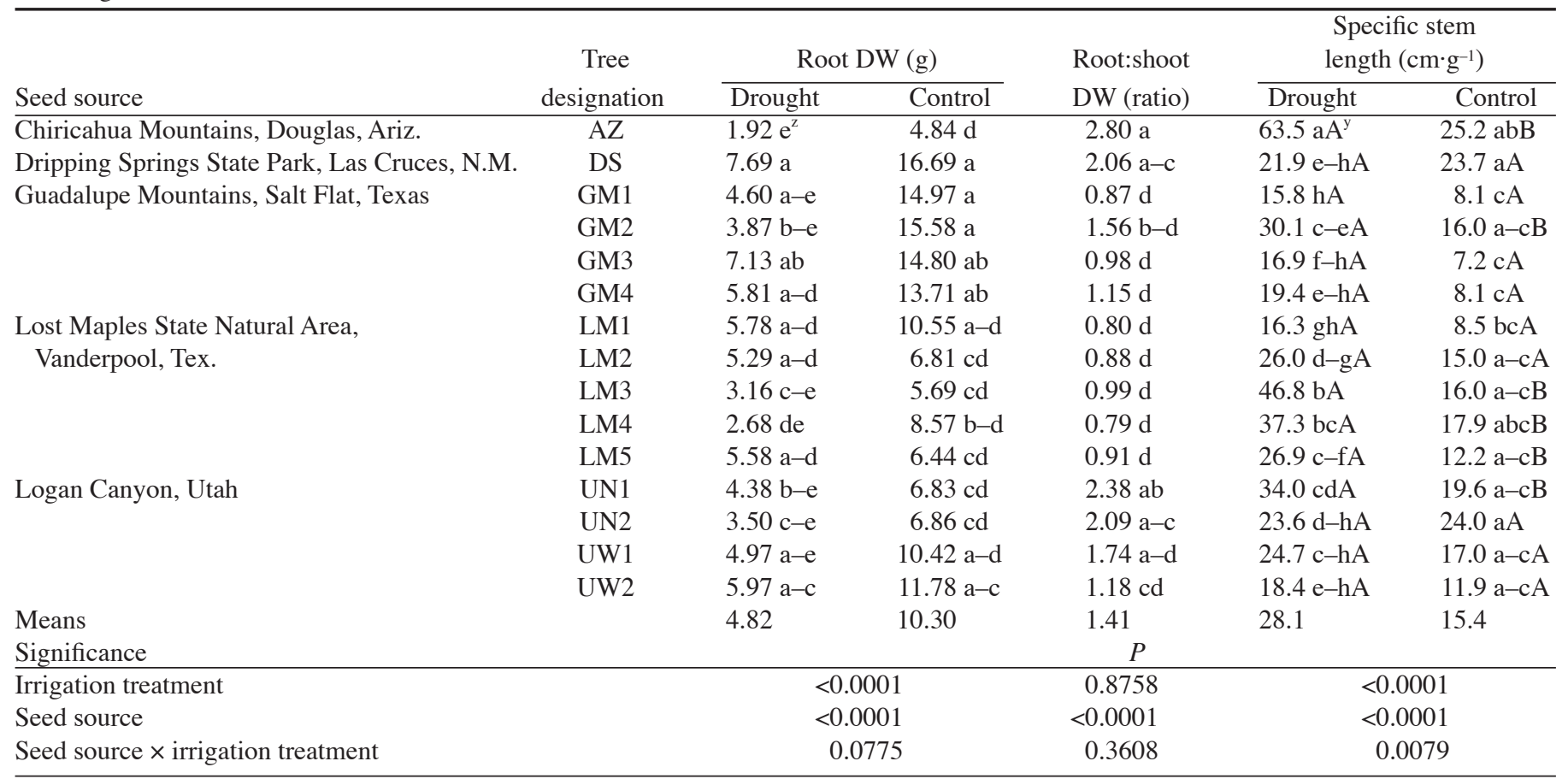

${ }_{\overline{\mathrm{Z}}}^{\mathrm{L}}$ east squares means (LSMeans) within a column sharing the same lowercase letter do not differ statistically.

${ }^{\mathrm{y}}$ For specific stem length, LSMeans within a treatment sharing the same uppercase letter do not differ statistically. LSMeans differences were assessed at $P \leq 0.05$ using the Proc Mixed, PDIFF option of SAS.

capacity of bigtooth maples to withstand low moisture in the growing substrate.

The rate of water loss is roughly proportional to $g_{\mathrm{s}}$ (Jones, 1998), so a positive and linear relationship between transpiration and $g_{\mathrm{s}}$ is expected. This relationship was true for $80 \%$ of the bigtooth maple plant sources that were tested and was exceptionally robust for plants from DS and LM2. The fact that we found no difference in variation $\left(r^{2}\right)$ for the regression equation $(P=$ 0.1081 ) (based on a test for differences between slopes) when both drought-stressed and well-irrigated plants within a source showed a linear relationship between transpiration and $g_{\mathrm{s}}$ is surprising. We hypothesized that the smaller stomatal aperture expected from drought-stressed bigtooth maple plants is likely to have a greater regulatory effect on transpiration. Thus, stressed 
plants should show less variation in that linear relationship. These results might be important for drought survival of these taxa because they imply that changes in transpiration are closely linked to $g_{\mathrm{s}}$ regardless of irrigation treatment. Because several plant sources show stomatal regulation of water loss, we suggest that the adjustment of leaf water status maybe a common drought adaptation mechanism in bigtooth maples.

Provenance of origin and irrigation treatment influenced RGR. But the efficiency with which bigtooth maple plants accumulate dry matter (NAR) is insensitive to provenance of origin. This suggests that NAR of bigtooth maples is stable in populations indigenous to a wide geographic region and is not a meaningful indicator of a provenance's fitness for arid environments. While their lower values for NAR suggest that drought-stressed plants were less efficient in accumulating dry matter than well-watered plants, NAR for drought-stressed plants were remarkably similar. The similarity of NAR among drought-stressed plants underscores the finding that NAR may not be a good trait to use for the selection of bigtooth maples for arid locations.

Relative growth rate is a proxy for the extent to which a plant invests its photosynthates in current growth and enhances its capacity for future photosynthesis (Fritter and Hay, 2002). We observed large variation in RGR among bigtooth maple plant sources. Resources available at a site impacts RGR. So, the observations of Barker (1975) and Sorenson et al. (1984) that suggest bigtooth maple is a slow-growing tree, must be tempered with information about the plant's provenance of origin and the environmental conditions of growth. Rapid growth could be advantageous for a landscape tree if environmental conditions such as water deficits do not severely limit growth (Balok and St. Hilaire, 2002). Furthermore, rapid and efficient growth in a drought-stressed environment is clearly a strategy that will enhance survival of bigtooth maples. Although NAR does not necessarily correlate with RGR (Poorter and Remkes, 1990), drought-stressed plants from DS, GM3, GM4, and LM1, LM2, LM5, UW1, and UW2 had relatively high NAR and RGR, suggesting that drought had limited impact on these plants.

Developmental traits associated with drought responses are important to quantifying plant drought adaptation mechanisms (Blum, 1996). Plants respond to drought by reducing total leaf area (Alves and Setter, 2004; Hennessey et al., 1985). This plasticity in leaf area is one strategy that plants may use to control water use. This might be true for plants from the Guadalupe Mountains. For example, GM3 plants exposed to drought, despite being among the three tallest plants sources, showed a $69 \%$ reduction in total leaf area compared to their well-watered controls. Drought-stressed plants from GM2, GM3, and GM4 were the three tallest plant sources.

In a greenhouse study of five woody perennial species considered as tolerant, intermediately sensitive, or sensitive to drought, root DW of all species declined after 10 weeks of drought treatment (Percival and Sheriffs, 2002). Similarly, all drought-stressed plants from the Guadalupe Mountains and Dripping Springs State Park had lower root DW than well-watered plants. In contrast, four of the five sources from Lost Maples State Natural Area maintained root DW values that were statistically similar for drought-stressed and control plants. While drought did not alter root to shoot DW allocation patterns, the maintenance of a large functional root system in plants from Lost Maples State Natural Area could confer a important drought survival trait to plants from this provenance. In maple taxa, such as black maples (Acer nigrum Michx. F.), investment in a large root system conferred fitness for survival in xeric environments (St. Hilaire and Graves, 2001).

Because SSL indicates length of stem allocated to each unit of biomass, this ratio could be used, in part, to determine a stem's mechanical strength. Drought-stressed plants had greater SSL in all seed sources (AZ, DS, GM2, LM3, LM4, LM4, LM5, and UN1) where SSL of drought-stressed and well-watered plants were different. Therefore, drought-stressed seedlings from these seed sources had thinner and weaker stems compared to their well-watered counterparts. Plants that maintained similar SSL between irrigation treatments such as those from GM1, GM3, GM4, LM1, LM2, and UW2 might be more desirable for arid environments.

The significant seed source by irrigation interaction for SSL (Table 3) may indicate variation in stem growth and developmental patterns of the plants after exposure to irrigation treatments. This variation might reflect differences in environmental conditions indigenous to the site of origin of our seed sources. For example, plants from low-light environments tend to have a higher SSL (Poorter, 1999). This enhances a plant's chances to escape the low-light surroundings through stem elongation (Poorter, 1999). Development of long stems while preserving stem mechanical strength is an adaptive advantage for plants exposed to a stressful environment. This is clearly evident for plants from GM1, GM3, and GM4, which had among the longest stems, and had the thickest and strongest stems.

The LAR, which indicates the proportion of total plant DW allocated to leaves (Poorter and Remkes, 1990) was stable among irrigation treatments. Drought did not affect root to shoot DW ratio. Furthermore, the leaf area/xylem diameter ratio, which indicates the ratio between tissues that transport water and those that photosynthesize (Balok and St. Hilaire, 2002), was not different between irrigation treatments. These results indicate that an altered biomass allocation pattern is not a widespread adaptation mechanism for bigtooth maples exposed to drought.

Physiological traits such as the regulation of water loss, maintenance of plant water status, and the efficiency of transport and photosynthetic systems may be particularly significant for these taxa. The evidence we have gathered suggests that this might be true. The RWC of bigtooth maples averaged $59 \%$, and did not vary with irrigation treatment or seed origin, suggesting that foliar tissues of bigtooth maples may endure low RWC yet maintain adequate photosynthesis. Photosynthetic activity is reduced when RWC ranges from $40 \%$ to $70 \%$ (Chaves, 1991). Neither SLW nor leaf thickness of bigtooth maples varied with irrigation treatment nor seed origin, suggesting there were no differences in leaf density. Assuming that SLW responds to drought because leaf density (mass per unit volume) and/or leaf thickness changes (St. Hilaire and Graves, 2001), and that a thicker leaf enhances photosynthetic capacity per unit area because photosynthetic proteins accumulate (Niinemets, 2001), we conclude that drought-stressed bigtooth maples appear to maintain foliar photosynthetic capacity per unit area.

Overall, drought adaptation mechanisms of bigtooth maples vary across geographical regions. However, drought adaptation mechanisms such as the favorably water status of drought-stressed plants from plant sources in Lost Maples State Natural Area, and the relatively high growth and efficient dry matter accumulation in drought-stressed plants from the Guadalupe Mountains suggest that selected plant sources from these provenances have the potential to flourish in arid environments. 


\section{Literature Cited}

Abrams, M.D., M.E. Kubiske, and K.C. Steiner. 1990. Drought adaptations and responses in five genotypes of Fraxinus pennsylvanica Marsh.: Photosynthesis, water relations and leaf morphology. Tree Physiol. 6:305-315.

Alves A.C. and T.L. Setter. 2004. The response of cassava leaf area expansion to water deficit. Cell proliferation, cell expansion, and delayed development. Ann. Bot. 94:605-613.

Balok, C.A. and R. St. Hilaire. 2002. Drought responses among seven southwestern landscape tree taxa. J. Amer. Soc. Hort. Sci. 127:211-218.

Barker, P.A. 1974. The spectacular canyon maple. Utah Sci. 35:7-10.

Barker, P.A. 1975. Acer grandidentatum and its propagation. Proc. Intl. Plant Prop. Soc. 25:33-38.

Barker, P.A. 1977. Fall foliage correlation as an objective for genetic improvement of a utah maple Acer grandidentatum Nutt. HortScience 12:410.

Baz, M. and R.T. Fernandez. 2002. Evaluating woody ornamentals for use in herbicide phytoremediation. J. Amer. Soc. Hort. Sci. 127:991-997.

Blum, A. 1996. Crop responses to drought and the interpretation of adaptation. Plant Growth Regulat. 20:135-146.

Chaves, M.M. 1991. Effects of water deficits on carbon assimilation. J. Expt. Bot. 42:1-16.

Dina, S.J., L.G. Klikoff, and M.B. Keddington. 1973. Seasonal water potential patterns in the mountain brush zone, Utah. Amer. Midland Naturalist 89:234-239.

Feser, C.F., R. St. Hilaire, and D. VanLeeuwen. 2005. Development of in-ground container plants of mexican elders exposed to drought. HortScience 40:446-450.

Fitter, A.H. and R.K.M. Hay. 2002. Environmental physiology of plants, 3rd ed. Academic, San Diego, Calif.

Gutschick, V.P. and L.E. Kay. 1995. Nutrient-limited growth rates: Quantitative benefits of stress responses and some aspects of regulation. J. Expt. Bot. 46:995-1009.

Handreck, K. and N. Black. 2002. Growing media for ornamental plants and turf. $3^{\text {rd }}$ ed. Univ. of New South Wales Press, Sydney, Australia.

Hennessey T.C, L.K. Bair, and R.W. McNew. 1985. Variation in response among three Alnus spp. clones to progressive water stress. Plant Soil $87: 135-141$.
Jones, H.G. 1998. Stomatal control of photosynthesis and transpiration. J. Expt. Bot. 49:387-398.

Kriebel, H.B. 1957. Patterns of genetic variation in sugar maple. Ohio Agr. Expt. Sta. Bul. 791.

Little, E.L., Jr. 1944. Acer grandidentatum in Oklahoma. Rhodora 46:445-450.

Mir, N., M. Wendorf, R. Perez, and R.M. Beaudry. 1998. Chlorophyll fluorescence in relation to superficial scald development in apple. J. Amer. Soc. Hort. Sci. 123:887-892.

Niinemets, U. 2001. Global-scale climatic controls of leaf dry mass per area, density, and thickness in trees and shrubs. Ecology 82:453-469.

Olson, D.F. and W.J. Gabriel. 1974. Seeds of woody plants in the United States. USDA For. Serv. Hdbk. No. 450.

Percival G.C. and C.N. Sheriffs. 2002. Identification of drought-tolerant woody perennials using chlorophyll fluorescence. J. Arboriculture 28:215-223.

Poorter, L. 1999. Growth responses of 15 rain-forest tree species to a light gradient: The relative importance of morphological and physiological traits. Functional Ecol. 13:396-410.

Poorter, H. and C. Remkes. 1990. Leaf area ratio and net assimilation rate of 24 wild species differing in relative growth rate. Oecologia 83:553-559.

Sorenson, E., C.F. Williams, R.H. Walser, J.D. Davis, and P. Barker. 1984. Growth response of Acer grandidentatum Nutt. to chilling treatments. J. Environ. Hort. 2:128-130.

Spurr, A.R. 1969. A low viscosity epoxy resin embedding medium for electron microscopy. J. Ultrastructural Res. 26:31-43.

St. Hilaire, R. and W.R. Graves. 1999. Foliar traits of sugar maples and black maples near $43^{\circ} \mathrm{N}$ latitude in eastern and central United States. J. Amer. Soc. Hort. Sci. 124:605-611.

St. Hilaire, R. and W.R. Graves. 2001. Stability of provenance differences during development of hard maple seedlings irrigated at two frequencies. HortScience 36:654-657.

St. Hilaire, R. 2002. Bigtooth maple: A plant that merits more use in southwestern landscapes. Landscape Plant News 13:10-11.

Tankersley, B.E. 1981. Growth and propagation of Acer grandidentatum Nutt. MS Thesis, Texas A\&M Univ., College Station.

Zwack, J.A., W.R. Graves, and A.M. Townsend. 1998. Leaf water relations and plant development of three freeman maple cultivars subjected to drought. J. Amer. Soc. Hort. Sci. 123:371-375. 